\title{
CORRELATION BETWEEN EMOTION REGULATION AND SCHOOL WELFARE AMONG STUDENTS IN URBAN AREA
}

\author{
Siswati, Frieda NRH, Jati Ariati \\ Faculty of Psychology, Universitas Diponegoro
}

\begin{abstract}
Background: Emotion regulation becomes increasingly important across adolescent development, and promotes psychological flexibility, resilience and well-being in youth. Emotion regulation has been related to a wide variety of domains of functioning, including social functioning, psychological and physical well-being, and academic performance. This study aimed to determine the correlation between emotion regulation and school welfare among students in urban area.

Subjects and Method: This was a cross sectional study conducted at a high school in Semarang, Central Java. A total sample of 113 students was selected for this study by cluster sampling. The dependent variable was emotion regulation. The independent variable was welfare. The data were collected by questionnaire and analyzed by chi square.

Results: Emotion regulation was associated with school welfare among students in urban area

Conclusion: Emotion regulation of student is associated with the school welfare.
\end{abstract}

Keywords: emotion regulation, school welfare, student

Correspondence:

Siswati. Faculty of Phsycology, Universitas Diponegoro. Email: siswatipsi@gmail.com.

The $5^{\text {th }}$ International Conference on Public Health

Best Western Premier Hotel, Solo, Indonesia, February 13-14, 2019 | 199

https://doi.org/10.26911/theicph.2019.02.35 